Original Research Article

\title{
Screening of liver protective effect of ethanolic leaf extract of Callicarpa lanata (EECL) in ethanol induced hepatotoxicity in wister rats
}

\author{
Zulfkar Latief Qadrie ${ }^{1 *}$, Rajkapoor Balasubramanium² ${ }^{2}$, Shakil U. Rehman ${ }^{3}$
}

\begin{abstract}
${ }^{1}$ Department of Pharmacology and Toxicology, Pratishta Institute of Pharmaceuticals Sciences, Suryapet, Hyderabad, Telangana, India

${ }^{2}$ Department of Pharmacology, Faculty of Medicine, Sebha University, Sebha, Libya ${ }^{3}$ Department of Pharmacology, Govt. Medical College, Baramulla, Jammu and Kashmir, India
\end{abstract}

Received: 03 January 2019 Accepted: 04 February 2019

\section{*Correspondence to:}

Dr. Zulfkar Latief Qadrie, Email: zulfkarzulfi@gmail.com

Copyright: (C) the author(s), publisher and licensee Medip Academy. This is an openaccess article distributed under the terms of the Creative Commons Attribution NonCommercial License, which permits unrestricted noncommercial use, distribution, and reproduction in any medium, provided the original work is properly cited.

\begin{abstract}
Background: The ethanolic extract of Callicarpa lanata (EECL), belonging to the family Verbenaceae, were studied for hepatoprotective activity in Wister rats with liver damage induced by ethanol.

Methods: Ethanol treated rats showed significant increase in the levels of serum enzyme activities, total bilirubin and reduction in total proteins reflecting the liver injury caused by ethanol. EECL, at a dose of 400 and $200 \mathrm{mg} / \mathrm{kg}$ body weight exhibited hepatoprotective effect by lowering the Serum Glutamate Pyruvate Transaminase (SGPT), Serum Glutamate Oxaloacetate Transaminase (SGOT), Serum Alkaline Phosphate (SALP), Gama Glutamyl Transpeptidase (GGTP), total Bilirubin to a significant extent and also significantly increased the levels of total protein in a dose dependent manner.

Results: The results were highly significant at dose level of $400 \mathrm{mg} / \mathrm{kg}$ body weight ( $\mathrm{p}<0.01$ ) and significant at dose level of $200 \mathrm{mg} / \mathrm{kg}$ body weight $(\mathrm{p}<0.05)$. The effects of EECL at both levels were comparable with standard drug silymarin. The hepatoprotective activity was also supported by histopathological studies of liver tissue.

Conclusions: In-vivo hepatoprotective activity of ethanolic leaf extract of Callicarpa lanata (EECL) against Ethanol induced acute liver injury in rats showed significant results in a dose dependent manner.
\end{abstract}

Keywords: Callicarpa lanata, Ethanol, Hepatotoxicity, Hepatocytes, Silymarin

\section{INTRODUCTION}

Number of deleterious metabolic changes in the liver are induced by alcohol. Steatosis, alcoholic hepatitis and cirrhosis resulting in weight and volume changes are caused by excessive use of alcohol for a long-time. ${ }^{1,2}$ Minimum $80 \%$ of heavy drinkers had been reported to develop steatosis, $10-35 \%$ alcoholic hepatitis, and approximately $10 \%$ liver cirrhosis. ${ }^{3}$ In recent studies, the animal models suggest that liver injury in chronic alcoholics is due to oxidative stress that leads to fibrosis and impaired liver functions and increased apoptosis. ${ }^{4}$

The medicinal use of many plants (as hepatoprotectives) like Andrographis paniculata, Azadirachta indica, Cassia fistula, Elephantopus scaber, Hibiscus rosasinensis, Indoneesiella echioides, Phyllanthus debilis, Picrorrhiza kurroa has been reported in the literature..$^{5-7}$ 
Callicarpa lanata. Family: Verbenaceae, an plant known worldwide as Tomex tomentosa L. Callicarpa tomentosa L. is widely used in tropical countries as a source of ethno medicines. It is recommended in a wide range of ailments including fever, Hepatic obstruction, hepatic eruption, skin diseases and used as a wash for aphthae in the mouth. ${ }^{8}$

Callicarpa lanata leaves contain $\beta$ - sitosterol, maslinic, oleanolic and ursolic acids and their methyl ester acetates, lupeol acetate and $\beta$-amyrin acetate; heartwood contains $\beta$ sitosterol and oleanolic acid. Bark contains methyl betulinate, baurenol and $\beta$-sitosterol acetate. ${ }^{9}$

Callicarpa lanata $\mathrm{EtOH}$ (50\%) extract of root and stem is antiviral and antifungal and plant extract is antiinflammatory in rats. ${ }^{10}$ The seeds are antiperiodic, antipyretic, antispasmodic, tonic, anthelmintic and febrifuge; useful in colic, malaria, fever, hydrocele and skin diseases. Decoction of the seed is used in kidney troubles and blood pressure. It is also useful against consumption and asthma. Seeds are also useful for swellings and restraining haemorrhage. The oil from the seeds is used in convulsions and paralysis. Pod is astringent to the bowels and anthelmintic; cures urinary discharges, leucorrhoea, piles and wounds. Decoction of the pod is used in bleeding piles. ${ }^{11}$

No scientific report is available relating the hepatoprotective potentials of Callicarpa lanata in ethanol induced liver damage. Therefore, the present work was planned to study the protective effect of ethanolic Callicarpa lanata (EECL) extract in acute ethanol-induced hepatotoxicity in rats.

\section{METHODS}

\section{Plant material}

The leaf Callicarpa lanata. were collected from Thiruvallur (dt) Tamil Nadu and dried. The shade dried leafs were powdered.

\section{Preparation of plant extract}

About $500 \mathrm{~g}$ of dried powder was extracted with ethanol by continuous hot percolation, using soxhlet apparatus. The concentrated crude extracts were lyophilized in to powder and used for the study. The extracts were dried under vacuum. The yield was $250 \mathrm{~g}$ with respect to $2 \mathrm{Kg}$ of dried powder and used for oral administration. ${ }^{11}$

\section{Preliminary phytochemical screening of Callicarpa lanata leaves}

Preliminary phytochemical tests have been conducted for the presence of alkaloids, carbohydrates, glycosides, phenolic compounds, tannins, protein and amino acids, saponins, gums and mucilage, sterols, fixed oils, fats and flavonoids. $^{12}$

\section{Experimental animals}

Wistar male albino rats weighing $150-200 \mathrm{~g}$ were used for the study. The rats were procured from Sri Venkateswara Enterprises, Bangalore, India. The animals were grouped and housed in polyacrylic cages $(38 \times 23 \times 10 \mathrm{~cm})$ with not more than six animals per cage and maintained under standard laboratory conditions (temperature $25 \pm 20^{\circ} \mathrm{C}$ ) with dark and light cycle $(12 / 12 \mathrm{~h})$. The animals were fed with standard pellet diet supplied by Hindustan Lever Ltd., Bangalore, India and fresh water ad libitum. All the animals were acclimatized to laboratory condition for a week before commencement of experiment. All procedures described were reviewed and approved by the University Animals Ethical Committee (UAEC).

\section{Drugs and chemicals}

Silymarin was purchased from Micro Labs. India. SGPT, SGOT, SALP, GGTP, Total Bilirubin and Total Protein kits were procured from Span Diagnostics, India. All other chemicals were of analytical grade and purchased from local suppliers.

\section{Experimental protocol}

In order to study the liver protective effect of Callicarpa lanata in rats, dose levels of 400 and $200 \mathrm{mg} / \mathrm{kg}$ bw p.o were used respectively. $40 \% \mathrm{v} / \mathrm{v}$ ethanol $(2 \mathrm{ml} / 100 \mathrm{~g}$ bw p.o.) was used as hepatotoxic chemical and Silymarin (100 $\mathrm{mg} / \mathrm{kg}$ bw p.o) was used as a standard drug in this study. Rats were divided into five groups as per following protocol. ${ }^{13-17}$

- Vehicle control ( $n=6$, Treated with normal saline only for 21 days).

- Hepatotoxic control ( $\mathrm{n}=6$, Treated with alcohol for 21 Days).

- Standard group ( $n=6$, Treated with alcohol +silymarin for 21 days).

- Treatment group I ( $\mathrm{n}=6$, Treated with alcohol + EECL $400 \mathrm{mg} / \mathrm{kg}$ bw p.o for 21 days).

- Treatment group II ( $\mathrm{n}=6$, Treated with alcohol + EECL $200 \mathrm{mg} / \mathrm{kg}$ bw p.o for 21 days).

At the end of the treatment, rats were sacrificed by cervical dislocation, blood samples were collected by direct cardiac puncture. The serum was used for the evaluation of marker enzymes. Liver was dissected out and washed with icecold saline and a homogenate was prepared in $0.1 \mathrm{~N}$ Tris HCL buffer ( $\mathrm{pH}$ 7.4). The homogenate was used for the assay of antioxidant marker enzymes.

\section{Biochemical estimation}

The levels of SGPT, SGOT, SALP, GGTP, total bilirubin and total protein were estimated in the serum using standard kits from Span India ltd, Surat, India. ${ }^{7}$ The liver homogenate was centrifuged by using high speed cooling centrifuge and supernatant was used for the assay of lipid 
peroxidation (LPO), super oxide dismutase (SOD), Catalase (CAT), reduced glutathione (GSH) and Glutathione peroxidase (GPX). ${ }^{18-21}$

\section{Histopathological studies}

The livers were excised quickly and fixed in $10 \%$ formalin and paraffin embedded. Sections of about 4-6 $4 \mathrm{~m}$ were stained with haemotoxylin and eosin (H\&E) for Histological evaluation. In brief 4-6 $\mu \mathrm{m}$ thick sections of paraffin embedded rat liver were dewaxed with distilled water for $2 \mathrm{~min}$. Then the section was stained with haemotoxylin for $5 \mathrm{~min}$ at room temperature. After $15 \mathrm{~min}$, the section was counterstained with eosin for $2 \mathrm{~min}$, dehydrated with alcohol, washed with xylene and blocked by eosin. Hemotoxylin and eosin stained studies were observed under microscope. . $2,23^{23}$

\section{Statistical analysis}

Data for hepatoprotective activity were expressed as Mean \pm SEM from six rats in each group. Hepatoprotective activity were analyzed statistically using one way analysis of variance (ANOVA), followed by Dunnett's ' $t$ ' test. P value of $<0.01$ was considered as highly significant and $<0.05$ as significant.

\section{RESULTS}

Preliminary phytochemical screening of Callicarpa lanata Leaf revealed the presence of various compounds; glycosides, alkaloids, flavonoids, tannins, phenols, saponins and sterols. Exposure of rats to alcohol for 21 days showed significantly $(\mathrm{p}<0.05)$ elevated levels of serum biochemical markers like SGPT, SGOT, SALP, GGTP, total bilirubin and total protein. The protective effect of Ethanolic extract of Callicarpa lanata Leaf on SGPT, SGOT, SALP, GGTP, total bilirubin and total protein in $40 \% \mathrm{v} / \mathrm{v}$ ethanol treated rats showed significant ( $\mathrm{p}<0.01 ; \mathrm{p}<0.05$, respectively) decline as compared to Hepatotoxic control group. The degree of hepatoprotection by Ethanolic extract of Callicarpa lanata. (EECL) (400 and $200 \mathrm{mg} / \mathrm{kg}$ bw p.o.) was observed statistically near value with the standard drug (Table 1 ). When comparing EECL $400 \mathrm{mg} / \mathrm{kg}$ were highly significant than EECL 200 $\mathrm{mg} / \mathrm{Kg}$ dose. The hepato-protective effects were seen in dose dependant manner.

Table 1: Results of ethanolic leaf extract Callicarpa lanata (EECL) on liver homogenates parameters against ethanol induced injury in rats.

\begin{tabular}{|c|c|c|c|c|c|c|c|}
\hline Groups & $\begin{array}{l}\text { Dose } \\
\text { (mg/kg, po) }\end{array}$ & $\begin{array}{l}\text { LPO } \\
\text { (mmol/mg) }\end{array}$ & $\begin{array}{l}\text { SOD } \\
\text { (U/mg) }\end{array}$ & $\begin{array}{l}\text { CAT } \\
\text { (U/mg) }\end{array}$ & $\begin{array}{l}\text { GPX } \\
\text { (U/mg) }\end{array}$ & $\begin{array}{l}\text { GST } \\
\text { (U/mg) }\end{array}$ & $\begin{array}{l}\text { GSH } \\
\text { (mmol/mg) }\end{array}$ \\
\hline $\begin{array}{l}\text { Vehicle } \\
\text { Control }\end{array}$ & $5 \mathrm{ml}$ & $0.49 \pm 0.09$ & $115.13 \pm 22.13$ & $28.5 \pm 6.45$ & $4.11 \pm 1.02$ & 1.04 & 0.3 \\
\hline Hepatotoxic & $2 \mathrm{ml} / 100 \mathrm{~g}$ & $4.14 \pm 1.04$ & $39.25 \pm 10.12$ & $10.34 \pm 5.14$ & $1.98 \pm 0.95$ & $0.55 \pm 0.09$ & $0.01=$ \\
\hline Standard & 100 & $0.50 \pm 0.12 * *$ & $98.32 \pm 15.95 * *$ & $27.11 \pm 3.68 * *$ & $3.82 \pm 1.35^{* *}$ & $0.98 \pm 0.09 * *$ & $0.29 \pm 0.12 * *$ \\
\hline Treatment I & 400 & $1.66 \pm 0.14 * *$ & $89.20 \pm 12.87 * *$ & $21.2 \pm 3.15^{* *}$ & $2.52 \pm 1.09 * *$ & $0.87 \pm 0.59 * *$ & $0.21 \pm 0.03 * *$ \\
\hline Treatment II & 200 & $2.51 \pm 0.12 *$ & $56.12 \pm 16.12 *$ & $17.71 \pm 3.15^{*}$ & $1.04 \pm 0.98 *$ & $0.50 \pm 0.89 *$ & $0.16 \pm 0.10 *$ \\
\hline
\end{tabular}

$\mathrm{n}=6$; values were expressed Mean \pm S.E.M; ; Group II was compared to Group I. Groups III to V were compared to group II. *p <0.01 vs. ethanol group: highly significant; ** p <0.05 vs. Ethanol group: significant. Data were analyzed by One-way ANOVA followed by Dunnett's ' $t$ ' test.

Table 2: Results of the effects of ethanolic leaf extract Callicarpa lanata (EECL) on the biochemical markers of ethanol induced hepatic injury in rats.

\begin{tabular}{|llllllll|}
\hline Groups & $\begin{array}{l}\text { Dose } \\
(\mathbf{m g} / \mathrm{kg}, \mathbf{p o})\end{array}$ & SGPT u/l & SGOT u/l & SALP u/l & $\begin{array}{l}\text { Total bilirubin } \\
(\mathbf{m g} / \mathbf{d l})\end{array}$ & GGTP u/l & $\begin{array}{l}\text { TP } \\
\text { mg/dl }\end{array}$ \\
\hline $\begin{array}{l}\text { Vehicle } \\
\text { control }\end{array}$ & $5 \mathrm{ml}$ & $80 \pm 0.74$ & $121 \pm 0.97$ & $138 \pm 1.72$ & $0.70 \pm 0.03$ & $124 \pm 0.95$ & $6.5 \pm 0.06$ \\
\hline Hepatotoxic & $2 \mathrm{ml} / 100 \mathrm{~g}$ & $372 \pm 0.58$ & $356 \pm 2.95$ & $410 \pm 0.08$ & $2.42 \pm 0.17$ & $254 \pm 2.65$ & $7.4 \pm 0.08$ \\
\hline Standard & 100 & $\begin{array}{l}105 \\
\pm 1.08 * *\end{array}$ & $\begin{array}{l}231 \\
\pm 1.46^{* *}\end{array}$ & $\begin{array}{l}198 \\
\pm 1.06 * *\end{array}$ & $\begin{array}{l}1.10 \\
\pm 0.03 * *\end{array}$ & $\begin{array}{l}117 \\
\pm 1.04 * *\end{array}$ & $\begin{array}{l}5.8 \\
\pm 0.02 * *\end{array}$ \\
\hline Treatment I & 400 & $\begin{array}{l}139.88 \\
\pm 8.22^{* *}\end{array}$ & $\begin{array}{l}206.28 \\
\pm 4.24 * *\end{array}$ & $\begin{array}{l}182.46 \\
\pm 8.22^{* *}\end{array}$ & $1.68 \pm 4.62 * *$ & $106 \pm 1.06^{*}$ & $\begin{array}{l}4.88 \\
\pm 8.12 * *\end{array}$ \\
\hline Treatment II & 200 & $\begin{array}{l}168.28 \\
\pm 6.76^{* *}\end{array}$ & $\begin{array}{l}166.84 \\
\pm 4.26^{*}\end{array}$ & $298 \pm 8.44 *$ & $2.06 \pm 2.20^{*}$ & $93 \pm 1.05^{*}$ & $3.9 \pm 0.04 *$ \\
\hline
\end{tabular}

$\mathrm{n}=6$; values were expressed Mean \pm S.E.M; Group II was compared to Group I. Groups III to V were compared to group II. $* \mathrm{p}<0.01$ vs. ethanol group: highly significant; ** p <0.05 vs. ethnol group: significant. Data were analyzed by One-way ANOVA followed by Dunnett's ' $t$ ' test. 
Standard drug silymarin also maintained the similar result. GSH test, showed much decreased level of glutathione in ethanol induced rats. Treatment with Callicarpa lanata showed significantly improved level. Similar activity was also observed with the standard drug silymarin. Rats treated with $40 \% \mathrm{v} / \mathrm{v}$ ethanol caused a significant $(\mathrm{p}<0.01)$ decline in the hepatic antioxidants such as SOD and CAT in comparison to normal control animals. In liver weight study, the liver weight of alcohol treated rats were highly increased (Table 3).

In histological examinations, hepatocytes of the normal control group showed a normal cellular architecture of the liver. Whereas the liver section of rats treated with toxicant showing intense centrilobular necrosis and vacuolization.

\section{Table 3: Results of ethanolic leaf extract Callicarpa lanata (EECL) on average liver weight of treated animals against ethanol.}

\begin{tabular}{|lll|}
\hline Groups & $\begin{array}{l}\text { Dose }(\mathrm{mg} / \mathrm{kg}, \\
\text { po) }\end{array}$ & $\begin{array}{l}\text { Liver weight }(\mathrm{g}) / 100 \mathrm{~g} \\
\text { of body weight }\end{array}$ \\
\hline $\begin{array}{l}\text { Vehicle } \\
\text { control }\end{array}$ & $5 \mathrm{ml}$ & $2.51 \pm 0.42$ \\
\hline Hepatotoxic & $2 \mathrm{ml} / \mathrm{Kg}$ & $4.96 \pm 0.73$ \\
\hline Standard & 100 & $2.64 \pm 0.18^{* *}$ \\
\hline Treatment I & 400 & $2.70 \pm 0.16^{* *}$ \\
\hline Treatment II & 200 & $3.2 \pm 0.24^{*}$ \\
\hline
\end{tabular}

$\mathrm{n}=6$, Values were expressed as mean \pm SEM. $* \mathrm{P}<0.01 \mathrm{Vs}$ ethanol, highly significant; **P $<0.05$ significant. Data were analyzed by One way ANOVA followed by Dunnett's ' $t$ ' test.

\section{DISCUSSION}

There are many factors which are responsible for the liver damage or injuries such as chemicals and drugs. In the present study ethanol was used to induce hepatotoxicity, since it is clinically relevant. Ethanol produces a constellation of dose related deleterious effects in the liver. ${ }^{24}$

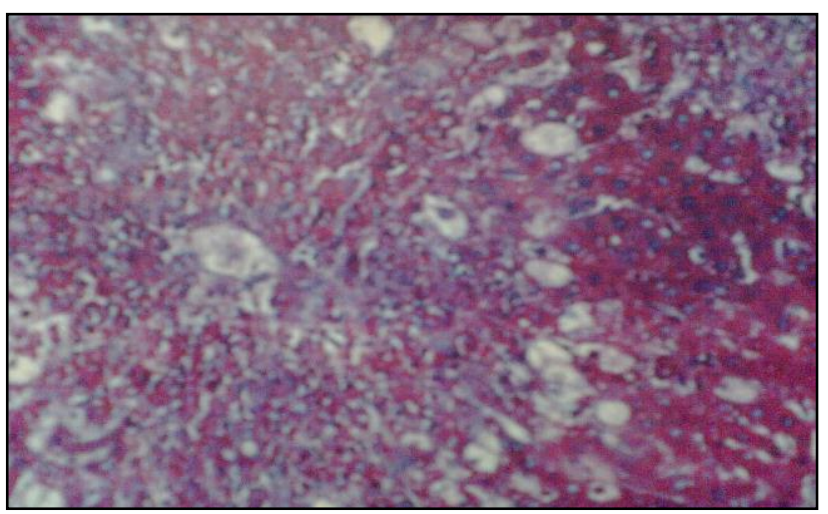

Liver section of vehicle control group, Haematoxylin and Eosin 100x showed normal structure of hepatic lobules, whereas black spots are glycogen, white spots indicate the presence of vacuoles, a prominent blood vein with normal appearance.

Figure 1: Vehicle control.

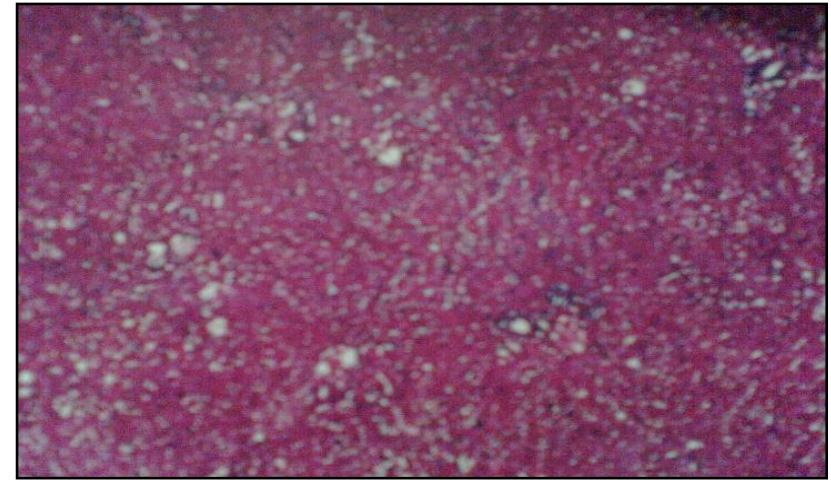

Liver section of Standard group, Haematoxylin and Eosin 100x showed normal structure of hepatic lobules, whereas black spots are glycogen, white spots indicate the presence of vacuoles, a prominent blood vein with normal appearance.

Figure 2: Silymarin $(100 \mathrm{mg} / \mathrm{Kg})$.

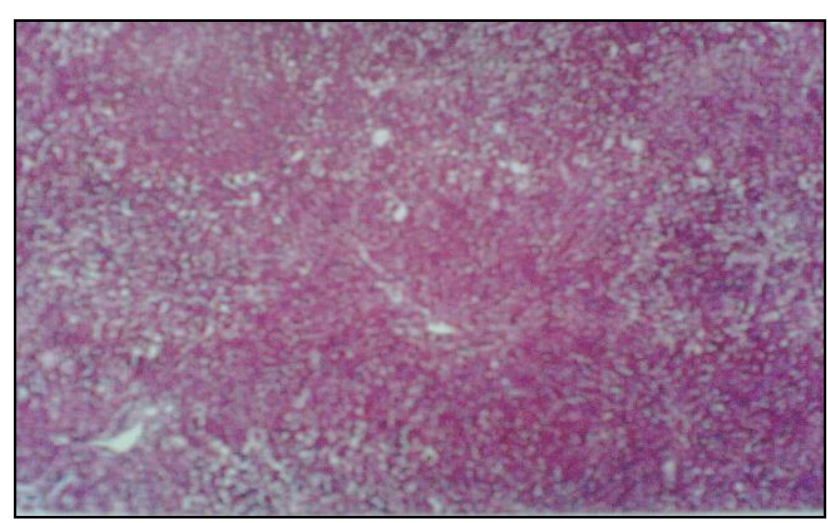

Liver section of Hepatotoxic control group. Haematoxylin and Eosin 100x. Section showed degeneration of hepatic parenchyma, moderate congestion and microvesicular changes.

Figure 3: Ethanol (40\% v/v) $2 \mathrm{ml} / \mathrm{Kg}$.

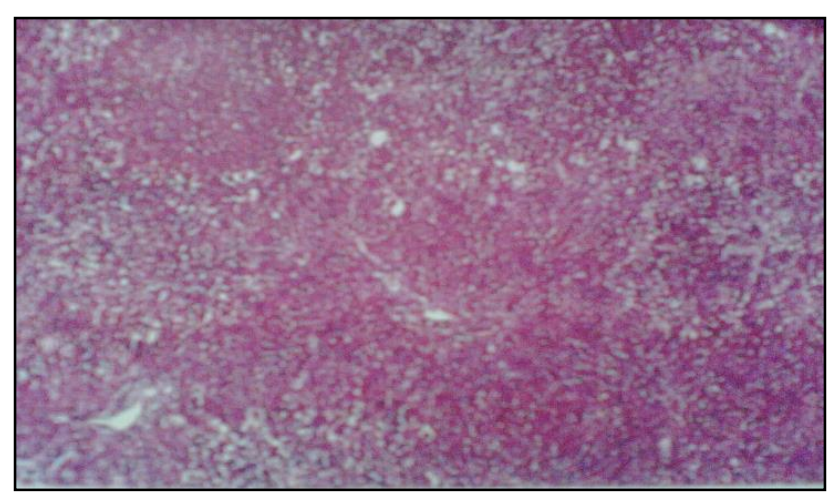

Liver section of treatment group I. Haematoxylin and Eosin 100x showed marked recovery in hepatic cells with nuclei, cytoplasm, central vein and portral traid.

Figure 4: Ethanolic leaf extract Callicarpa lanata (EECL) $(400 \mathrm{mg} / \mathrm{kg})$.

The majority of ethanol is metabolized in the liver and individuals who abuse alcohol by routinely drinking 50-60 $\mathrm{g}$ (about 4 to 5 drinks) of ethanol per day are at risk for developing alcoholic liver disease. ${ }^{25}$ In addition, both acute 
and chronic ethanol administration cause enhanced formation of cytokines, especially TNF-alpha by hepatic Kupffer cells, which have a significant role in liver injury. ${ }^{26-28}$ Besides the development of fatty liver (steatosis), another early sign of excessive ethanol consumption is liver enlargement, both of which are common findings in alcoholics and heavy drinkers. ${ }^{29,30}$

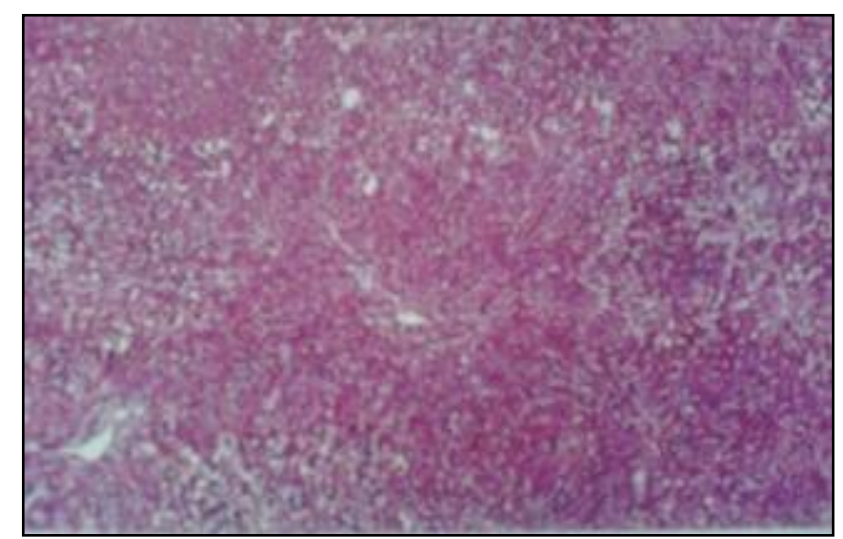

Liver section of treatment group II. Haematoxylin and Eosin 100x Section showed recovering ruptured cells, necrosis, walls of blood vein and less vacuolisation with disappearance of nuclei.

\section{Figure 5: Ethanolic leaf extract Callicarpa lanata (EECL) (200mg/kg).}

Elevated levels of serum glutamic oxaloacetic transaminase (SGOT) and serum glutamic pyruvic transaminase (SGPT) are indications of hepatocellular injury. ${ }^{31}$ In the present study EECL at a dose levels of $400 \mathrm{mg} / \mathrm{kg}$, po caused a significant inhibition in the levels of SGOT and SGPT towards the respective normal range and this is an indication of stabilization of plasma membrane as well as repair of hepatic tissue damage caused by ethanol. On the other hand, suppression of elevated SALP and reduction of raised bilirubin level and an increase in the total plasma protein content suggests the improvement of biliary dysfunction in rat liver during hepatic injuries with toxicants. ${ }^{32}$

These results indicate that EECL preserved the structural integrity of the hepatocelluar membrane and liver cell architecture damaged by ethanol which was confirmed by histopathological examination viz., Figure 1 shows vehicle control, liver section of vehicle control group, showed normal structure of hepatic lobules, whereas black spots are glycogen, white spots indicate the presence of vacuoles, a prominent blood vein with normal appearance. Figure 2 shows Silymarin $(100 \mathrm{mg} / \mathrm{Kg})$, liver section of Standard group, showed normal structure of hepatic lobules, whereas black spots are glycogen, white spots indicate the presence of vacuoles, a prominent blood vein with normal appearance. Figure 3 gives information Ethanol (40\% v/v) $2 \mathrm{ml} / \mathrm{Kg}$; liver section of Hepatotoxic control group, showed degeneration of hepatic parenchyma, moderate congestion and microvesicular changes. Figure 4 illustrates Ethanolic leaf extract Callicarpa lanata (EECL) $(400 \mathrm{mg} / \mathrm{kg})$; liver section of treatment group I, showed marked recovery in hepatic cells with nuclei, cytoplasm, central vein and portral traid. Figure 5 represents ethanolic leaf extract Callicarpa lanata (EECL) $(200 \mathrm{mg} / \mathrm{kg})$; liver section of treatment group II, showed recovering ruptured cells, necrosis, walls of blood vein and less vacuolisation with disappearance of nuclei.

\section{CONCLUSION}

In conclusion, Ethanolic extract of Callicarpa lanata is effective against oxidative liver damage induced by alcohol administration. So, this study will give the pharmacological support to use of folk medicine in the management of alcohol intoxicated hepatic damage.

Funding: No funding sources

Conflict of interest: None declared

Ethical approval: The study was approved by the Institutional Ethics Committee

\section{REFERENCES}

1. Muhammad Habib-ur-Rehman, Zafar Hussain, Fakhar Hameed. Protection against Ethanol induced Hepatotoxicity by Silymarin in Albino Rats. Ann Pak Inst Med Sci. 2009; 5(4):206-10.

2. Muhammad Habib-ur-Rehman, Mohammad Tahir, Khalid P. Lone and Waqas Sami. Ethanol induced Hepatotoxicity in Albino Rats. J Coll Physicians Surg Pak. 2011;21(10):642-43.

3. Saravanan N, Nalini N. Antioxidant effect of Hemidesmus indicus on ethanol induced hepatotoxicity in rats. J Med Food. 2007;10:675-82.

4. Ronis MJ, Hakkak R, Korourian S, Albano E, Yoon S, Ingelman-Sundberg $\mathrm{M}$, et al. Alcoholic liver disease in rat fed ethanol as part of oral or intragastric lowcarbohydrate liquid diets. Exp Biol Med. 2004; 229:351-60.

5. Rajesh MG, Latha MS. Hepatoprotection by Elephantopus scaber Linn. in CCl4-induced liver injury. Indian J Physiol Pharmacol. 2001 Oct;45(4):481-6.

6. Anandan R, Rekha RD, Devaki T. Protective effect of Picrorhiza kurroa on mitochondrial glutathione antioxidant system in D-galactosamine-induced hepatitis in rats. Curr Sci. 1999 Jun 25;76(12):1543-5.

7. Qadrie ZL, Anandan R, Jacob B, Ashraf H. Liver Protective Activity of Indoneesiella Echioides Against Carbon Tetrachloride (CCl4)-Induced Hepatotoxicity In Rats. Pharmacologyonline. 2011;2:416-29.

8. Nadkarni AK, Nadkarni KM. Indian Materia Medica. Bombay: Popular Prakashan. 1975;1:252-53.

9. Ghani A. Medicinal Plants of Bangladesh with Chemical Constituents and Uses. 2nd Edn. Asiatic Society of Bangladesh; 1998: 266-67.

10. Asolkar LV, Kakkar and Chakre. Second Supplement to Glossary of Indian Medicinal Plants with active principles. Part-I (A-K), CSIR, New Delhi. 1992:12930 . 
11. Zulfkar Q, Balasubramanian R, Kavimani S. Acute and Subacute Toxicity of Callicarpa linata leaf Extracts in Rats. Int J Pharm Research Sci. 2013 Nov;2(11):1095-104.

12. Kokate CK, Purohit AP, Gokhale SB. A Text Book of Pharmacognosy. 28th Ed., Nirali Prakashan. 2004:119.

13. Leo MA, Lieber CS. Hepatic fibrosis after long-term administration of ethanol and moderate vitamin A Supplementation in the rat. Hepatol. 1983;3(1):111.

14. Arulkumaran KS, Rajasekaran A, Ramasamy R, Jegadeesan M, Kavimani S, Somasundaram A. Cassia roxburghii seeds protect liver against toxic effects of ethanol and carbontetrachloride in rats. Int $\mathbf{J}$ Pharm Tech Res. 2009;1(2):273-6.

15. Dahiru D, Obidoa O. Evaluation of the antioxidant effects of Ziziphus mauritiana lam. leaf extracts against chronic ethanol-induced hepatotoxicity in rat liver. African $\mathrm{J}$ TraditionalComplementary Alternative Med. 2008;5(1):39-45.

16. Saka WA, Akhigbe RE, Ishola OS, Ashamu EA, Olayemi OT, et al. Hepato therapeutic effect of Aloevera in alcohol induced Hepatic damage. Pak J Bio Sci. 2011;14(14):742-46.

17. Vetriselvan S, Subasini U, Victor Rajamanickam C, Thirumurugu S. Hepatoprotective activity of Andrographis paniculata in ethanol induced hepatotoxicity in albino wistar rats. Pharma Globale. 2011;2(2):1-4

18. Wilber KM. Bernheim Fshapiro OW. Determination of lipid peroxidation. Arch Biochem. 1949;24:305-10.

19. Kono Y. Generation of superoxide radical during autoxidation of hydroxylamine and an assay for superoxide dismutase. Arch Biochem Biophysics. 1978 Feb 1;186(1):189-95.

20. Hugo EB. Oxidoreductase activity on groups other than $\mathrm{CHOH}$ : Catalase. In:Colowick SP, Kaplan NO, Packer L, eds. Methods in Enzymology. London: Academic Press. 1984:121-125.

21. Rani P, Unni KM, Karthikeyan J. Evaluation of antioxidant properties of berries. Indian $\mathbf{J}$ Clin Biochem. 2004 Jul 1;19(2):103-10.

22. Alquasoumi SI, Al-Dosari MS, Al-Sheikh AM, Abdel Kader MS. Evaluation of the hepatoprotective effect of Fumaric parviflora and Momordica balsamine from
Saudi flock medicine against experimentally induced liver injury in rats. Res J Med Plant. 2009;3:9-15.

23. Srilakshimi SV, Vijayan P, Vsantha Raj P, Dhanaraj SA, et al. Hepatoprotective properties of Caesalpinia sappan Linn. heartwood on carbon tetrachloride induced toxicity. Ind J Exp Biol. 2010;48:905-10.

24. Leo MA, Arai M, Sato M, Lieber CS. Hepatotoxicity of vitamin A and ethanol in the rat. Gastroenterol. 1982 Feb 1;82(2):194-205.

25. Zakhari S, Li TK. Determinants of alcohol use and abuse: impact of quantity and frequency patterns on liver disease. Hepatol. 2007 Dec;46(6):2032-9.

26. Zhou Z, Wang L, Song Z, Lambert JC, McClain CJ, Kang YJ. A critical involvement of oxidative stress in acute alcohol-induced hepatic TNF- $\alpha$ production. Am J Pathol. 2003 Sep 1;163(3):1137-46.

27. Thurman RG. II. Alcoholic liver injury involves activation of Kupffer cells by endotoxin. Am J Physiol Gastrointestinal Liver Physiol. 1998 Oct 1;275(4):G605-11.

28. Tsukamoto H, Takei Y, McClain CJ, Joshi-Barve S, Hill D, Schmidt J, et al. How is the liver primed or sensitized for alcoholic liver disease?. Alcoholism Clin Experiment Res. 2001 May 1;25:171S-81S.

29. Baraona E, Leo MA, Borowsky SA, Lieber CS. Alcoholic hepatomegaly: accumulation of protein in the liver. Science. 1975 Nov 21;190(4216):794-5.

30. Baraona E, Leo MA, Borowsky SA, Lieber CS. Pathogenesis of alcohol-induced accumulation of protein in the liver. J Clin Investigation. 1977 Sep 1;60(3):546-54.

31. Yue M, Ni Q, Yu CH, Ren KM, Chen WX, Li YM. Transient elevation of hepatic enzymes in volunteers after intake of alcohol. HBPD INT. 2006 Feb;5(1):525.

32. Mukherjee PK. Quality control of herbal drugs: an approach to evaluation of botanicals. Business Horizons. 2002:531.

Cite this article as: Qadrie ZL, Balasubramanium R, Rehman SU. Screening of liver protective effect of ethanolic leaf extract of Callicarpa lanata (EECL) in ethanol induced hepatotoxicity in wister rats. Int $\mathbf{J}$ Basic Clin Pharmacol 2019;8:595-600. 